\title{
New-Keynesian economics tales with algebraic notations
}

\author{
Dushko Josheski*
}

Researcher in the field of applied economics, and small Keynesian macroeconomic models

$$
\text { University Goce Delcev-Stip ,R.Macedonia }
$$

\begin{abstract}
In this paper are outlined some new-keynesian economic models along with their micro foundations. At first small model of interest rate consumption income and savings has been outlined. Modigliani-Miller model follows as one of the five neutralities in macroeconomics, and demand for money by Miller and Orr. Also Baumol-Tobin models with its extensions by Jovanovic and Romer has been subject to investigation. Issues in monetary policy such as printing money and government revenues of printing money are been subject to discussion too. In the last section Diamond-Dybvig model on bank runs is being outlined.
\end{abstract}

Keywords: New-Keynesian economics, interest rate, monetary policy, money demand, bank runs

JEL codes: E12,E60,E50

*Correspondent author email: dushkojosheski@gmail.com 


\section{Introduction}

Keynesian economics since The General Theory revealed one fundamental error of classical economics that equilibria in a capitalist economy can persist but with high involuntary unemployment. But also Keynes showed that aggregate demand play crucial role in determining the output and employment. Keynesian economics it is said that violates the assumptionthat good economics is conditioned by, and that is the notion that microeconomic foundation are based on perfectly rational economic agents, Akerlof, Yelen $(1980)^{1}$.During the decade of 1960's and 1970's Keynesians have struggled to formulate micro foundations for their Keynesian models and they were relaxing the Walrasian assumptions by introducing market imperfections such asasymmetric informations,Akerlof(1970) ${ }^{2}, \operatorname{Stiglitz(1976)}$ ${ }^{3}$,staggered $\quad$ contracts, Taylor $(1980)^{4}$, transaction cost theories papers such as:

${ }^{1}$ Akerlof, George A \&Yellen, Janet L, (1987). "Rational Models of Irrational Behavior," American Economic Review, American Economic Association, vol. 77(2), pages 137-42, May

${ }^{2}$ Akerlof, George A, 1970. "The Market for 'Lemons': Quality Uncertainty and the Market Mechanism," The Quarterly Journal of Economics, MIT Press, vol. 84(3), pages 488-500, August.

${ }^{3}$ M. Rothschild, J. E. Stiglitz: "Equilibrium in Competitive Insurance Markets: An Essay on the Economics of Imperfect Information", Quarterly Journal of Economics, 90, 1976, 629649.

${ }^{4}$ Taylor,B.,J.,(1980), Aggregate dynamics and staggered contracts, The journal of political economy, Vol.88
Baumol(1952) $)^{5}$,Tobin $(1956)^{6}$.Now, in the following sections of the paper are explained some of the new-keynesian economics tale along with some proofs. .

\section{Interest rate consumption income and savings}

A representative consumer maximizes:

$\int_{0}^{\infty} \mathrm{u}[\mathrm{c}(\mathrm{t})] \mathrm{e}^{-\delta \mathrm{t}} \mathrm{dt}(1)$

Subject to

$\dot{\mathrm{a}}=\mathrm{y}+\mathrm{ra}-\mathrm{c}, \mathrm{a}(0)$ is givenwhere $\mathrm{y}$ and rare constant through time, $\mathrm{y}$ is perishable output, and a represents a stock of interestbearing real financial assets. We do not necessarilyimpose that the subjective discount rate $\delta$ is equal to the market real interest rate $\mathrm{r}$. A no-Ponzi condition also is imposed on the problem. This means that for a consumer with a market discount factor $\rho_{\mathrm{t}}$ we have the following budget constraint:

$$
B_{t} \leq E_{t} \sum_{s=1}^{\infty} \beta^{s} \frac{\rho_{t+s}}{\rho_{t}}\left(Y_{t+s}-C_{t+s}\right)
$$

\footnotetext{
${ }^{5}$ Baumol, William J., (1952), "The Transactions Demand for Cash: An Inventory Theoretic Approach", Quarterly Journal of Economics, November, vol. 66, pp. 545-556.

${ }^{6}$ Tobin, James, (1956), “The Interest Elasticity of the Transactions Demand for Cash", Review of Economics and Statistics, August, vol. 38, no. 3, pp. 241-247.
} 
This corresponds to a period budget constraint and no -ponzi condition of form:

$C_{t} \leq Y_{t}-\beta^{-1} \rho_{t}^{-1} B_{t-1}+B_{t}(3)$

$\lim _{T \rightarrow \infty} E_{t}\left[\beta^{T} \rho_{t+T} B_{t+T}\right](4)$

For the isoelastic function we have

$\mathrm{u}(\mathrm{c})=\frac{\mathrm{c}^{1-\frac{1}{\sigma}}-1}{1-\frac{1}{\sigma}}(5) \mathrm{y}$ and $\mathrm{r}$, are constant

through time

Hamiltonian for this problem is:

$H=u(c)+\lambda(y+r a-c)(6)$

First order conditions are:

$\frac{\partial \mathrm{H}}{\partial \mathrm{c}}=\mathrm{u}^{\prime}(\mathrm{c})-\lambda=0(7)$

$\dot{\lambda}=\lambda \delta-\frac{\partial \mathrm{H}}{\partial \mathrm{c}}=\lambda(\delta-\mathrm{r})(8)$

$0=\lim _{t \rightarrow \infty} e^{-\delta t} \lambda(t) a(t)(9)$

First derivative of consumption is:

$\mathrm{u}^{\prime}(\mathrm{c})=\mathrm{c}^{-1 / \sigma}(10)$

The last equation can be written as:

$\mathrm{u}^{\prime \prime}(\mathrm{c}) \dot{\mathrm{c}}=\mathrm{u}^{\prime}(\mathrm{c})(\delta-\mathrm{r})(11)$

Or as

$\frac{\dot{\mathrm{c}}}{\mathrm{c}}=\frac{-\mathrm{u}^{\prime}(\mathrm{c})}{\mathrm{cu}^{\prime \prime}(\mathrm{c})}(\delta-\mathrm{r})=\sigma(\mathrm{r}-\delta)(12)$

The solution for linear differential equation describing consumption path is:

$c(t)=c(0) e^{\sigma(r-\delta) t}(13)$ integrating $\mathrm{a}(0)$, and imposing no-ponzi condition preventing unlimited debt, the intertemporal budget constraint is :

$\mathrm{a}(0)=\int_{0}^{\infty}[\mathrm{c}(\mathrm{t})-\mathrm{y}] \mathrm{e}^{-\mathrm{rt}} \mathrm{dt}(14)$

if we substitute the equation for $c(t)$ in the last equation than we need to solve the equation:

$\mathrm{a}(0)=\int_{0}^{\infty}\left[\mathrm{c}(0) \mathrm{e}^{\sigma(\mathrm{r}-\delta) \mathrm{t}}-\mathrm{y}\right] \mathrm{e}^{-\mathrm{rt}} \mathrm{dt}(15)$

$c(0)=\frac{\mathrm{a}(0)+\left(\frac{\mathrm{y}}{\mathrm{r}}\right)}{\int_{0}^{\infty}\left[\mathrm{e}^{\sigma(\mathrm{r}-\delta) \mathrm{t}}\right] \mathrm{e}^{-\mathrm{rt}} \mathrm{dt}}=\frac{\mathrm{a}(0)+\left(\frac{\mathrm{y}}{\mathrm{r}}\right)}{\int_{0}^{\infty} \mathrm{e}^{\sigma(\mathrm{r}-\delta) \mathrm{t}-\mathrm{rt}} \mathrm{dt}}=$ $\frac{\mathrm{a}(0)+\left(\frac{\mathrm{y}}{\mathrm{r}}\right)}{[\sigma(\mathrm{r}-\delta)-\mathrm{t}]^{-1}\left\{\left.\mathrm{e}^{[\sigma(\mathrm{r}-\delta) \mathrm{t}-\mathrm{r}] \mathrm{t}}\right|_{0} ^{\infty}\right\}}=[\sigma \delta-$ $(\sigma-1) \mathrm{r}]\left[\mathrm{a}(0)+\left(\frac{\mathrm{y}}{\mathrm{r}}\right)\right](16)$

The assumption that $(\sigma-1) \mathrm{r}-\sigma \delta=$ $\sigma(\mathrm{r}-\delta)<0, \lim _{\mathrm{t} \rightarrow \infty} \mathrm{e}^{[\sigma(\mathrm{r}-\delta) \mathrm{t}-\mathrm{r}] \mathrm{t}}=0$

Looking at the preceding consumption function, we see the three ways a rise in the interest rate $r$ will affect saving:

The marginal propensity to consume out of total wealth is $\sigma \delta-(\sigma-1) \mathrm{r}$ : When $\mathrm{r}$ rises, that coefficient falls with an effect proportional to $\sigma$. This is the substitution effect.The substitution effect is counteracted by an effect proportional to unity that tends to make $\sigma \delta-(\sigma-1) \mathrm{r}$ to rise when $r$ rises. This is the income effect. The coefficient $(\sigma-1)$ in the marginal propensity $\sigma \delta-(\sigma-1) r$ captures the 
balance between the substitution and income effects. In addition, $\mathrm{y} / \mathrm{r}$ falls when $\mathrm{r}$ rises - there is a fall in lifetime wealth and

\section{Modigliani-Miller theorem}

Firms raise capital by issuing debt as well as equity too. So the firm can issue equity shares $\mathrm{E}$, and bonds $\mathrm{B}$, to finance its investment in capital K. Forms can find itself in two states $\mathrm{S}$, and in two periods. The payoff to the investment tomorrow is $\mathrm{A}(\mathrm{s}) \mathrm{F}(\mathrm{K})$ fors $\in \mathrm{S}$. For simplicity assumption of depreciation of capital is that $\delta=1$. Risk free interest rate on the markets is, firms borrowing rate is $\tilde{\mathrm{r}}$. The firm will owe to its bondholders $(1+\tilde{\mathrm{r}}) \mathrm{B}$ in every state but the bankruptcy states are given as $S_{B}$ and non-bankruptcy states are given as $\mathrm{S}_{\mathrm{NB}}$. And the total set of states is the one that consists of bankruptcy and non-bankruptcy states $S=S_{B} \cup S_{N B}$. When in bankruptcy, the total output of the firm is insufficient to cover debt payments; $\operatorname{so}(\mathrm{s}) \mathrm{F}(\mathrm{K})<(1+\tilde{\mathrm{r}}) \mathrm{B}$. In this case bondholders are senior claimants and get whatever there it is while equity holders get nothing.

equity holder payoff

$$
=\left\{\begin{array}{l}
A(s) F(K)-(1+\tilde{r}) B \forall S \in S_{N B} \\
0 \forall S \in S_{B}
\end{array}\right.
$$

bond holder payoff $=\left\{\begin{array}{l}(1+\tilde{\mathrm{r}}) \mathrm{B} \forall \mathrm{S} \in \mathrm{S}_{\mathrm{NB}} \\ \mathrm{A}(\mathrm{s}) \mathrm{F}(\mathrm{K}) \forall \mathrm{S} \in \mathrm{S}_{\mathrm{B}}\end{array}\right.$ so consumption falls. This is the wealth effect.

The value of the equity of the firm is given as:

$\mathrm{E}=\sum_{\mathrm{S} \in \mathrm{S}_{\mathrm{NB}}} \frac{\mathrm{p}(\mathrm{s})(\mathrm{A}(\mathrm{s}) \mathrm{F}(\mathrm{K})-(1+\tilde{\mathrm{r}}) \mathrm{B})}{1+\mathrm{r}}=\mathrm{K}-\mathrm{B}$

In order lenders to get the same rate of return as they would in risk free lending we can write;

$\sum_{S \in S_{N B}} \frac{p(s)(1+\tilde{r}) B}{1+r}+\sum_{S \in S_{B}} \frac{p(s) A(S) F(K)}{1+r}=B$

$1+\tilde{r}=\frac{B-\sum_{s \in S_{B}} \frac{p(s) A(S) F(K)}{1+r}}{\sum_{S \in S_{N B}} \frac{p(s)(1+\tilde{r}) B}{1+r}}(19)$

$\mathrm{V}=\mathrm{E}+\mathrm{B}=\sum_{\mathrm{s} \in \mathrm{S}_{\mathrm{NB}}} \frac{\mathrm{p}(\mathrm{s}) \mathrm{A}(\mathrm{S}) \mathrm{F}(\mathrm{K})-(1+\tilde{\mathrm{r}}) \mathrm{B}}{1+\mathrm{r}}+$

$\sum_{\mathrm{S} \in \mathrm{S}_{\mathrm{NB}}} \frac{\mathrm{p}(\mathrm{s})(1+\tilde{\mathrm{r}}) \mathrm{B}}{1+\mathrm{r}}+\sum_{\mathrm{S} \in \mathrm{S}_{\mathrm{B}}} \frac{\mathrm{p}(\mathrm{s}) \mathrm{A}(\mathrm{S}) \mathrm{F}(\mathrm{K})}{1+\mathrm{r}}=$

$\sum_{\mathrm{S} \in \mathrm{S}} \frac{\mathrm{p}(\mathrm{s}) \mathrm{A}(\mathrm{S}) \mathrm{F}(\mathrm{K})}{1+\mathrm{r}}=\mathrm{K}$

Previous expression is the basic Modigliani-Miller theorem, the firm's market value is simply the value of its outputs across future states of nature. The division of claims between equity and debt is irrelevant. Also, this theorem is irrelevant for the investment rule, i.e. investment rule is unaffected by the mode of finance, debt or equity. The Tobin's q is 
more sophisticated it assumes that capital is costly to install. Key assumption of the model is that there exist convex installation costs $\frac{\chi}{2}\left(\mathrm{I}^{2} / \mathrm{K}\right)$. This are the cost that incur for the installing the new capital. So, therefore firm's discounted profit stream at date $\mathrm{t}$ can be presented:

$\Pi(\mathrm{t})=\int_{\mathrm{t}}^{\infty} \mathrm{e}^{-\mathrm{r}(\mathrm{s}-\mathrm{t})}[\mathrm{A}(\mathrm{s}) \mathrm{F}(\mathrm{K}(\mathrm{s}), \mathrm{L}(\mathrm{s}))-$ $\mathrm{w}(\mathrm{s}) \mathrm{L}(\mathrm{s})-\mathrm{I}(\mathrm{s})-\frac{\chi}{2}\left(\mathrm{I}(\mathrm{s})^{2} / \mathrm{K}(\mathrm{s})\right] \mathrm{ds}$

The last expression is maximized subject to constraint, $\dot{\mathrm{K}}(\mathrm{s})=\mathrm{I}(\mathrm{s})$. The interest rate is assumed to be constant. Hamiltonian for this case is:

$\mathrm{H}=\mathrm{AF}(\mathrm{K}, \mathrm{L})-\mathrm{wL}-\mathrm{I}-\frac{\chi}{2}\left(\mathrm{I}^{2} / \mathrm{K}\right)+\mathrm{qI}$

We differentiate with respect to the two controls setting the result to zero, to obtain:

$\mathrm{AF}_{\mathrm{L}}(\mathrm{K}, \mathrm{L})=\mathrm{w}$

$\frac{\mathrm{I}}{\mathrm{K}}=\frac{\mathrm{q}-1}{\chi}(23)$

Investment is positive when the value of installed capital exceeds the replacement cost.

$\dot{\mathrm{q}}-\mathrm{rq}=-\frac{\partial \mathrm{H}}{\partial \mathrm{K}}(24)$

That is by:
$\dot{\mathrm{q}}-\mathrm{rq}=-\mathrm{AF}_{\mathrm{K}}(\mathrm{K}, \mathrm{L})-\frac{\chi}{2}(\mathrm{I} / \mathrm{K})^{2}(25)$

Dynamic equations of the model can be written as:

$\dot{\mathrm{q}}-\mathrm{rq}=-\mathrm{AF}_{\mathrm{K}}(\mathrm{K}, \overline{\mathrm{L}})-\frac{(\mathrm{q}-1)^{2}}{2 \chi}$

$\dot{\mathrm{K}}=\left(\frac{\mathrm{q}-1}{\chi}\right) \mathrm{K}(27)$

The steady state of the models incur where $\overline{\mathrm{q}}=1$ and $\mathrm{AF}_{\mathrm{K}}(\mathrm{K}, \mathrm{L})=\mathrm{r}$.Now, the general solution for a constant interest rate is given as:

$$
\begin{aligned}
& \mathrm{q}(\mathrm{t})=\int_{\mathrm{t}}^{\infty} \mathrm{e}^{-\mathrm{rt}}\left[\mathrm{AF}_{\mathrm{K}}(\mathrm{K}(\mathrm{s}), \mathrm{L}(\mathrm{s}))+\right. \\
& \left.\frac{\chi^{2}}{2}\left(\frac{\mathrm{I}(\mathrm{s})}{\mathrm{K}(\mathrm{s})}\right)^{2}\right] \mathrm{ds}+\mathrm{be}^{\mathrm{rt}}(28)
\end{aligned}
$$

Where we have made substitution

$\frac{(\mathrm{q}-1)^{2}}{2 \chi}=\frac{\chi}{2}\left(\frac{\mathrm{I}}{\mathrm{K}}\right)^{2}$

The economically relevant solution imposes the transversality condition:

$\lim _{t \rightarrow \infty} e^{-r t} q(t) K(t)=0(30)$

Which obliges us to set $b=0$ in that case:

$\mathrm{q}(\mathrm{t})=\int_{\mathrm{t}}^{\infty} \mathrm{e}^{-\mathrm{rt}}\left[\mathrm{AF}_{\mathrm{K}}(\mathrm{K}(\mathrm{s}), \mathrm{L}(\mathrm{s}))+\right.$ $\left.\frac{\chi^{2}}{2}\left(\frac{\mathrm{I}(\mathrm{s})}{\mathrm{K}(\mathrm{s})}\right)^{2}\right] \mathrm{ds}(31)$

This way defined is marginal $\mathrm{q}$, the relationship between average and marginal q I given this way: 
$\frac{\mathrm{d}(\mathrm{qK})}{\mathrm{dt}}=\mathrm{q} \dot{\mathrm{K}}+\dot{\mathrm{q}} \mathrm{K}=\operatorname{rqK}\left(\mathrm{AF}_{\mathrm{K}} \mathrm{K}+\frac{\chi \mathrm{I}^{2}}{2 \mathrm{~K}}\right)+$

$\mathrm{qI}=\mathrm{rqK}-\left[\mathrm{AF}(\mathrm{K}, \mathrm{L})-\mathrm{wL}+\frac{\chi^{2}}{2 \mathrm{~K}}\right]+$

$\mathrm{I}\left(1+\chi \frac{\mathrm{I}}{\mathrm{K}}\right)=\mathrm{r}(\mathrm{qK})-[\mathrm{AF}(\mathrm{K}, \mathrm{L})-\mathrm{wL}-$

$\left.\mathrm{I}-\chi \frac{\mathrm{I}^{2}}{2 \mathrm{~K}}\right](32)$

Imposing the transversality condition

$\mathrm{q}(\mathrm{t}) \mathrm{K}(\mathrm{t})=\int_{\mathrm{t}}^{\infty} \mathrm{e}^{-\mathrm{r}(\mathrm{s}-\mathrm{t})}[\mathrm{A}(\mathrm{s}) \mathrm{FK}(\mathrm{s}), \mathrm{L}(\mathrm{s})-$

$\left.\mathrm{w}(\mathrm{s}) \mathrm{L}(\mathrm{s})-\mathrm{I}(\mathrm{s})-\frac{\chi}{2}\left(\frac{\mathrm{I}(\mathrm{s})^{2}}{\mathrm{~K}(\mathrm{~s})}\right)\right] \mathrm{ds}=\Pi(\mathrm{t})$

From the previous expression one can see

that marginal $\mathrm{q}$ and average $\mathrm{q}$ are equal

i.e.:

$\mathrm{q}=\frac{\Pi}{\mathrm{K}} \cdot(34)$

\section{Miller-Orr model}

This is inventory model of the demand for money. Following Miller \&Orr (1966) ${ }^{7}$ model and Baumol(1952) and Tobin (1956), now generalizing Irving Fischer, Akerlof $(1969)^{8}$, lets demand for money to be written as:

$\mathrm{L}=\mathrm{L}(\mathrm{P}, \mathrm{S})(35)$

Where $\mathrm{P}$ are autonomous payment flows, actually $\mathrm{P}$ is a vector of probabilities of nonzero autonomous payments, $\mathrm{S}$ is

${ }^{7}$ Miller, M. \& Orr, D. (1966). A model of the demand for money by firms. The Quarterly Journal of Economics, 81, 413435

${ }^{8}$ Akerlof, George A, 1979. Irving Fisher on His Head: The Consequences of Constant Threshold-Target Monitoring of Money Holdings, The Quarterly Journal of Economics, MIT Press, vol. 93(2), pages 169-87, May. representing policies whereby bank accounts are monitored, or $\mathrm{S}$ are the monitoring rules whereby banks are monitored to have them prevented of them having too high or too low balance. Irving Fischer $\mathrm{S}$, is a vector of time intervals that present average lag which purchases follow autonomous receipts in different banks. In the standard monetarist theory of Irving Fisher persons receive money on their bank accounts. The flows are proportional to income.

$\mathrm{L}=\mathrm{L}\left(\mathrm{Y}, \frac{\mathrm{P}(\mathrm{Y}, \mathrm{r}, \mathrm{E})}{\mathrm{Y}}, \mathrm{S}\right)(36)$

In the previous expression $\mathrm{Y}$ denotes aggregate income, $r$ is the rate of interest and $E$ is the vector of aggregate expenditures, the probabilities of non-zero transactions depend on income, interest rate and expenditures so: $\mathrm{P}=$ $\mathrm{P}(\mathrm{Y}, \mathrm{E}, \mathrm{r}) \cdot$.Most theories on demand for money state:

$\mathrm{L}=\mathrm{L}(\mathrm{P}(\mathrm{Y}), \mathrm{S}(\mathrm{Y}, \mathrm{r}))(37)$

$\mathrm{S}$ in the previous expression is the monitoring rule. If the monitoring rule is constant and income changes, the demand for money will change proportionately. The implication is that short run demand for money is proportional to income, so this will make LM curve vertical in the short run so shifts in IS curve have no effect on equilibrium. We can modify Miller \&Orr model so that : 


$$
p+q+s=1(38)
$$

Where $\mathrm{p}$ is probability of getting one dollar, q is probability of losing one dollar, $\mathrm{S}$ is the probability of no transition. So, that expected value of autonomous payments and expected value of induced payments is zero. First let's consider the distribution of money holdings:

$f \mid p, q, s, h, z(39)$

$\mathrm{f}(\mathrm{x})$ is dependent only on $\mathrm{p} / \mathrm{q}, \mathrm{h}$ and $\mathrm{z}$. One can find this by setting $f(x, t)=p f(x-1, t-1)$ $+\operatorname{sf}(x, t-1),+q f(x+1, t-1)$. Now if we denote long run demand for money as $\mathrm{m}_{\mathrm{t}}^{*}$, and demand for money in the previous period as $m_{t-1}$. So that $m_{t}$ is the geometric mean of real money balances. This means that:

$\mathrm{m}_{\mathrm{t}}=\left(\mathrm{m}_{\mathrm{t}}^{*}\right)^{\mathrm{Y}}\left(\mathrm{m}_{\mathrm{t}-1}\right)^{1-\mathrm{Y}}(40)$

Suppose that long run demand for money depends upon income and interest:

$\mathrm{m}_{\mathrm{t}}^{*}=\mathrm{y}_{\mathrm{t}}^{\mathrm{a}}+\mathrm{r}_{\mathrm{t}}^{-\beta}(41)$

Where in the previous expression $\mathrm{m}_{\mathrm{t}}^{*}$ is the L-R demand, a is the L-R income elasticity of demand, $\beta$ is the L-R interest elasticity of demand. Then we can write like:

$\mathrm{m}_{\mathrm{t}}=\mathrm{y}_{\mathrm{t}}^{\mathrm{aY}} \mathrm{r}_{\mathrm{t}}^{\mathrm{a} \beta} \mathrm{m}_{\mathrm{t}-1}^{1-\mathrm{Y}}(42)$

And if we put the previous expression in logarithm: $\operatorname{lnm}_{t}=a \gamma \ln Y_{t}-\beta \gamma \ln r_{t}+(1-y) \operatorname{lnm}_{t-1}$

In the previous expression $\gamma$ is the rate of adjustment, a $\gamma$ represents short run income elasticity of the demand, $\beta \gamma$ is the shortrun elasticity of the demand, a represents long-run income elasticity of the demand, $\beta$ represents long run interest elasticity of the demand. Ignoring the constant term one can write following equation:

$\operatorname{lnm}_{\mathrm{t}}=\alpha \gamma \sum_{\mathrm{i}=0}^{\infty}(1-\gamma)^{\mathrm{i}} \operatorname{lny}_{\mathrm{t}-1}-$ $\beta \gamma \sum_{\mathrm{i}=0}^{\infty}(1-\gamma)^{\mathrm{i}} \ln r_{\mathrm{t}-1}$

Now, the level of investment is the constant fraction of the deviation of the capital stock from the optimum:

$\mathrm{I}_{\mathrm{t}}=\mathrm{K}_{\mathrm{t}}-\mathrm{K}_{\mathrm{t}-1}=\alpha\left(\mathrm{K}_{\mathrm{t}}^{*}-\mathrm{K}_{\mathrm{t}-1}\right)(45)$

In the previous expression $\mathrm{K}_{\mathrm{t}}^{*}$ is some function, let us say of income, the cost of capital, and maybe cost of labor. Caballero, Engel, and Haltiwanger $(1997)^{9}$, call the deviation from desired capital stock from actual "mandated investment". In the previous expression $\mathrm{K}_{\mathrm{t}}^{*}-\mathrm{K}_{\mathrm{t}-1}$ is the mandated investment. If the fraction of investment gap between $\mathrm{K}_{\mathrm{t}}^{*}-\mathrm{K}_{\mathrm{t}-1}$ is namedA(x), in other words

\footnotetext{
${ }^{9}$ Caballero, Ricardo J \& Engel, Eduardo M R A \&Haltiwanger, John, (1997). Aggregate Employment Dynamics: Building from Microeconomic Evidence, American Economic Review, American Economic Association, vol. 87(1), and pages 115-37, March.
} 
the investment rate of the firm than will be:

$\frac{\mathrm{I}}{\mathrm{K}}=\mathrm{A}(\mathrm{x}) \mathrm{xor}$

$\mathrm{I}=\int \mathrm{A}(\mathrm{x}) \mathrm{f}(\mathrm{x}) \mathrm{dx}(46)$ Proportional money supply is $\mathrm{p}^{*}$, and this proportional money supplyp ${ }^{*}=m$, also $\mathrm{p}^{*}$ is the long run optimal price, and the loss of non-setting the optimal price is:

$\mathrm{k}(\mathrm{p}-\mathrm{p} *)^{2}(47)$

Let's suppose that there is fixed costs of changing price, denoted a .Now, let's suppose that $\log$ of the money supply follows random walk. With, probability $1 / 2$ the gap $p-p^{*}$ rises by 1 . And with probability $1 / 2 p-p^{*}$ falls by 1 . Than the optimal policy has upper threshold: $\mathrm{p}^{*+\mathrm{U}}$ at which $p$ is set to equal its target value $\mathrm{p}^{*}$. A, symmetric lower threshold is: $\mathrm{p}^{*}-\mathrm{U}$. So, an optimal cash policy according to Miller and Orr (1966) ${ }^{10}$, will ask for an investment in a periodical receipts in the earning assets followed by regular timed sequence of security transfers

\section{Issues in monetary policy}

In general central government has monopoly power to issue money, and also this privilege is a source of revenue. Now, if the private sector is willing to hold paper money that the government supplies, the

\footnotetext{
${ }^{10}$ Miller, M.,Orr,D.,(2000), Amodel of the demand for money by firms, Quarterly Journal of Economics
}

government can buy real goods and services that the private sector produces with money that is costless for government top print. Money that is not backed by some real commodity are called fiat money. The real resources that government acquires by printing fiat money are equal to its seigniorage revenue. To define the seignoriage, we first need to know why the private sector is willing to accept the government's fiat money, all that matters is that there is demand for it. Seigniorage in period $t$ is given by the expression:

$\frac{M_{t}-M_{t-1}}{P_{t}}(49)$

From the last expression one can see that real resources that government acquires through increases in the nominal money balances the public is willing to hold. A useful way to rewrite this is to write:

$\frac{M_{t}-M_{t-1}}{P_{t}}=\pi m_{t-1}+\left(m_{t}-m_{t-1}\right)(50)$

In the previous expression $\pi_{\mathrm{t}}=\frac{\mathrm{P}_{\mathrm{t}}-\mathrm{P}_{\mathrm{t}-1}}{\mathrm{P}_{\mathrm{t}}}$, and money demand is $\mathrm{m}=\frac{\mathrm{M}}{\mathrm{P}}$, this expression emphasizes two distinct sources of seigniorage. First, the inflation tax, the amount people must give to the government to hold their real money balances constant in that face of rising prices. Second, it is the public desire to alter its real money holdings, given the inflation rate. Seigniorage at time $t$ is: 
$\frac{\dot{\mathrm{M}}(\mathrm{t})}{\mathrm{P}(\mathrm{t})}=\pi(\mathrm{t}) \mathrm{m}(\mathrm{t})+\dot{\mathrm{m}}(\mathrm{t})(51)$

We observe that seigniorage need not to equal the inflation. In the classic application of the interrelatedness between seigniorage and monetary policy by Sargent and Walace $(1981)^{11}$, it is said that monetary base is closely connected to the inflation, represented by the price level, and that the monetary authority can raise seignorage, by which is meant revenues from creation of money. We know the following identity: $i=r+\pi$, i.e. that nominal interest rate equals real plus the inflation, so one can solve:

$\frac{\mathrm{d}}{\mathrm{d} \pi} \pi \mathrm{m}(\mathrm{r}+\pi)=0(52)$

The last expression yields the following result:

$m+\pi m^{\prime}(i)=0(53)$

Or this can be rewritten:

$-\frac{\pi m^{\prime}(i)}{m}=1(54)$

From the last formula one can point out to the money demand curve where the inflation elasticity is 1 . This is standard formula that instruct us to look at money demand curve where the inflation elasticity is 1. And also standard formula where marginal costs of producing money equals

\footnotetext{
${ }^{11}$ Thomas J. Sargent \& Neil Wallace, 1981. "Some unpleasant monetarist arithmetic," Quarterly Review, Federal Reserve Bank of Minneapolis, issue Fall.
}

to marginal revenue from creating it. Nominal money supply $M$ is not changed at time $\mathrm{t}=0$ when $\pi$ rises.

$m^{\prime}(i)=\frac{d m}{d \pi}=\frac{-M}{P^{2}} \frac{d P}{d \pi}=-\frac{1}{P} \frac{d P}{d \pi} m(55)$

The equation for the total discounted seigniorage revenue reduces to:

$$
\int_{0}^{\infty} \mathrm{e}^{-\mathrm{rt}}\left[\left(\mathrm{m}+\pi \mathrm{m}^{\prime}(\mathrm{i})\right] \mathrm{dt}(56)\right.
$$

This solution is somewhat problematic because it entails an unexpected expropriation of private sector wealth to:

$\frac{1}{\mathrm{P}} \frac{\mathrm{dP}}{\pi} \mathrm{m}(57)$

Let's suppose that the government has promised to avoid surprise changes in the value of real balances, so in such a case small rise in inflation would rise government seigniorage revenue by:

$\mathrm{m}^{\prime}(\mathrm{i})+\int_{0}^{\infty} \mathrm{e}^{-\mathrm{rt}}\left[\left(\mathrm{m}+\pi \mathrm{m}^{\prime}(\mathrm{i})\right] \mathrm{dt}(58)\right.$

The reason to ensure $\mathrm{dP}=0$ when inflation rises, the government must reduce the nominal supply sharply, it might finance this loss in seigniorage by selling bonds, and it cannot finance it by a surprise inflation tax on the private sector as before. If we set the last expression to be equal to zero one can find that:

$\mathrm{m}^{\prime}(\mathrm{i})+\frac{\mathrm{m}+\pi \mathrm{m} /(\mathrm{i})}{\mathrm{r}}=0(59)$

Or after the simplification:

$-\frac{\mathrm{im}(\mathrm{i})}{\mathrm{m}}=1(60)$ 
This is the solution which sets interest elasticity of the demand for money to be equal to 1 . Now, if the initial private money balances are $\mathrm{m}_{0}$, and initial price level, at different levels of $i$. Now, one can find that:

$$
\int_{0}^{\infty} \mathrm{e}^{-\mathrm{rt}} \mathrm{im}(\mathrm{i}) \mathrm{dt}-\mathrm{m}_{0}(61)
$$

And the economy wide resource constraint one can set by the following formulation:

$f(0)=\int_{0}^{\infty} e^{-r t}[c(t)+g(t)-y(t)] d t$

this constraint comes from the fact that domestic money is not held by foreigners, and domestic residents hold no money issued by foreign governments.

\section{Baumol-Tobin model}

Baumol-Tobin model is and economic model of transaction demand ${ }^{12}$,this model was developed by Baumol(1952), and Tobin (1956). Later was extended by Jovanovic(1982) ${ }^{13}$ and Romer (1986). First,one can start by using the utility function from Romer (1987) ${ }^{14}$

$U=\int_{t=0}^{T} \operatorname{lnc}(t) d t-\operatorname{an}(63)$

\footnotetext{
${ }^{12}$ Transaction demand in Keynesian economics is one of the determinants of the demand for money.

${ }^{13}$ Jovanovic, Boyan, (1982), "Inflation and Welfare in the Steady State", Journal of Political Economy, vol. 90, no. 3, pp. 561-577.

${ }^{14}$ Romer,D.,(1987), The monetary transmission mechanism in a general equilibrium version of the Tobin-Baumol model, Journal of Monetary Economics, 20(1987
}

In the previous expression capital letter $\mathrm{T}$ is the life time of the consumer, $\mathrm{C}(\mathrm{t})$ is the consumption at some age $t$, that lies in the interval between 0 and T. Also, $a$ is the interval between withdrawals money from bank $a \in[0, \tau]$. While, $\mathrm{n}$ is the total number of conversions of bank deposits into money that individual makes throughout his life time. Now in the equilibrium model one must introduce inflation $\pi(t)$ and interest rate $i(t)$.Now, if the nominal interest rate is constant the number of trips to the bank would be given as per this expression:

$\tau=\sqrt{\frac{2 \mathrm{a}}{\mathrm{i}}}(64)$

But if one solves the utility function will get following result:

$\mathrm{U}=\operatorname{Tlnc}(\mathrm{t})-\operatorname{an}(65)$

Higher inflation on the other hand makes it more costly one to hold money, so the real money balances are reduced by an increase in frequency in which people convert their capital into money.

$\frac{\partial \tau}{\partial \pi}<0(66)$

Real money balances are equal to $=\bar{x}-b$ , where $\mathrm{m}$ are real money balances or $\frac{m}{p}, \bar{x}$ represents the capital that has been bought $b$ represents the cost of marketing the capital. This marketing cost in Jovanovic (1982) model represents same as 
brokerage fee in Tobin and Baumol models. Otherwise government expands or shrinks the money supply by constant rate $\pi$, the period during which an individual is using his real money balances is $\tau$. Now let:

$\mathrm{m}=\mathrm{c}(\mathrm{m}, \pi, \tau) \int_{0}^{\tau} \mathrm{e}^{\pi \tau} \mathrm{dt}(67)$

now when solving the integral $\int_{0}^{\tau} \mathrm{e}^{\pi \tau} \mathrm{dt}$ with replacing $u=\pi \tau$ and $d u=\pi d \tau$ or $\frac{\mathrm{du}}{\pi}=\mathrm{d} \tau$, and if one replace $\int_{0}^{\tau} \mathrm{e}^{\mathrm{u}} \frac{1}{\pi} \mathrm{du}$ we can simplify so that $\int \frac{\mathrm{e}^{\mathrm{u}}}{\pi}$ dunow the result from last expression is $\frac{e^{\mathrm{u}}}{\pi}$, now if one replace $u=\pi \tau$ and solves for $\frac{e^{\pi \tau}}{\pi}+C$, and with upper minus lower bound the result is $\frac{\mathrm{e}^{\pi \tau}-1}{\pi}$. And now one can write:

$m=c(m, \pi, \tau) \frac{e^{\pi \tau}-1}{\pi}(68)$

or:

$c(m, \pi, \tau)=\frac{m \pi}{e^{\pi \tau}-1}(69)$

so when inflation is $\pi>0$,inflation erodes purchasing power parity of money and so $c(m, \pi, \tau)<\frac{m}{\tau}(70)$

Inflation also is greater or equal to the negative rate of time preferences $a$

$\pi \geq-a(71)$

The brokers fee that individual pays for withdrawal of assets is given as $\frac{b T}{c}$, and if he holds cash his annual interest cost than will be $\frac{i c}{2}$.Now in order to find minimal costs in order individual to pay for his we apply first derivative with respect to $c$ on $\frac{b T}{c}+\frac{i c}{2}$

$-\frac{b T}{c^{2}}+\frac{i}{2}=0(72)$

or of one simplifies for $\mathrm{c}$ in the last expression one can get:

$c=\sqrt{\frac{2 b T}{i}}(73)$

or either way the general solution in the inventory models for demand of money is given by the expression, Baumol,Tobin(1989) $)^{15}$ :

$\frac{M}{\mathrm{an}}=\sqrt{\frac{\tau Y}{2 i a n}}(74)$

Now for a micro-foundations of the previous equation. Here shortly will be introduced the model by Miguel Sidrauski $(1968)^{16}$.This model is about individual household utility, total welfare of the family is given by :

$\mathrm{W}=\int_{0}^{\infty}\left[U\left(c_{t}, m_{t}\right)\right] e^{-a t} d t(75)$

\footnotetext{
${ }^{15}$ Baumol, William J. and Tobin, James (1989), "The Optimal Cash Balance Proposition: Maurice Allais' Priority", Journal of Economic Literature, September, Vol. 27, No. 3, pp. 11601162.

${ }^{16}$ Sidrauski, Miguel (May 1967). "Rational Choice and Patterns of Growth in a Monetary Economy". American Economic Review 57 (2): 534-544.
} 
The previous equation input can be presented as:

$W=\int_{0}^{\infty} \frac{\left[U\left(c_{t}, m_{t}\right)\right]}{e^{a t}} d t(76)$ or:

$\int_{0}^{\infty}\left[U\left(c_{t}, m_{t}\right)\right] e^{-a t} d t=\frac{\left[U\left(c_{t}, m_{t}\right)\right]}{a}(77)$

The last expression means that wealth of households depends on utility proportionally, but it decreases as subjective time preferences of the family grow. Utility depends on real money balances. The following identity it has been imposed:

$y\left(k_{t}\right)+g_{t}=c_{t}+s_{t}(78)$

$y\left(k_{t}\right)$ is the homogenous output that is produced by the capital stock, $g_{t}$ are the government transfers, $c_{t}+s_{t}$ is the real consumption plus gross real savings. Rate of time preferences can be presented by the following equation ${ }^{17}$ :

$e^{-a n}=1-\operatorname{an}(79)$

And the interval between trips to bank $\tau$ can be presented by the following formulation:

$\tau=\frac{T}{n+1}=\sqrt{\frac{2 a}{i}}(80)$ Which is the expression that previously has been derived. Now consumer spends in different ages of his life time. The utility maximization principle requires that at the

\footnotetext{
${ }^{17}$ Romer,D.(1986), A simple general equilibrium version of the baumol-tobin model*, The quarterly journal of economics
}

margin individual is indifferent whether he or she will spend at $t_{0}$ or at some later time t, i.e. $t_{0}<t<t_{1}$, individual withdraw money at $t_{0}$ and spends it at $t_{1}$.

$\frac{\mathrm{U} \prime\left(\mathrm{c}\left(\mathrm{t}_{0}\right)\right)}{\mathrm{p}\left(\mathrm{t}_{0}\right)}=\frac{\mathrm{U}(\mathrm{c}(\mathrm{t}))}{\mathrm{p}(\mathrm{t})}(81)$

In the previous expression $p$, represents the nominal price of the consumption good. In this version output can be written as in usual way $=f(k)$, and the usual assumptions here hold that $f^{\prime}(\cdot)>0$ $f^{\prime \prime(\cdot)}<0, \quad f^{\prime}(0)=\infty$ and $f^{\prime \prime}(\infty)=0$. The real interest rate is $r=f^{\prime}(k)$. The wage is $E=y-r k$. Now if $\mathrm{W}$ is the individual wealth or that is $W=E+S$, where is the initial Endowment that person receives at his/hers birth and $\mathrm{S}$ are the lump sum transfers that individual receives throughout his/hers lifetime. And, $w=\frac{W}{T}$, or $\mathrm{w}=\frac{\mathrm{E}+\mathrm{S}}{\mathrm{T}}$, consumption also at age $\mathrm{t}$ is given by the expression:

$c(t)=w e^{r j \tau} e^{-\pi(\tau-j \tau)}(82)$

In the previous expression $j \tau$ is the time interval where $\mathrm{j} \tau<t<(j+1) \tau$, last expression implies abot the contribution of generations to the total consumption:

$C_{j}=\frac{1}{T} \int_{0}^{(j+1) \tau} w e^{r j \tau} e^{-\pi(\tau-j \tau)} d t=$ $\frac{1}{\mathrm{~T}} \frac{1-\mathrm{e}^{-\pi \tau}}{\pi} e^{r j t} w(83)$

The total consumption is $C=\sum_{j=0}^{n} C_{j}=\left[\frac{1-e^{-\pi \tau}}{\pi}\right]\left[\frac{e^{r T}-1}{e^{\tau}-1} \frac{\tau}{T}\right] w$, and 
for $=\frac{w}{r}\left[\frac{\tau}{T} \frac{e^{r T}-1}{e^{r T}-1}-1\right]$, now substituting the last two expressions in :

$\frac{1}{T} \int_{0}^{T} C(t) d t=\frac{E}{T}+r_{0} \frac{1}{T} \int_{0}^{T} K(t) d t(84)$

One can get

$\mathrm{W}=\frac{\mathrm{E}+\mathrm{S}}{\mathrm{T}}=\frac{\pi \tau}{1-\mathrm{e}^{-\pi \tau}} \frac{\mathrm{E}}{\mathrm{T}}(85)$

Now in the extension Romer inserts government in the model. Government can inject money not by transferring to individuals but by purchasing goods. So, now the extension of the models looks a like this:

$\mathrm{G}=\frac{\mathrm{E}}{\mathrm{T}}+\mathrm{r}_{0} \frac{1}{\mathrm{~T}} \int_{0}^{\mathrm{T}} \mathrm{K}(\mathrm{t}) \mathrm{dt}-\frac{1}{\mathrm{~T}} \int_{0}^{\mathrm{T}} \mathrm{C}(\mathrm{t}) \mathrm{dt}(86)$

In this economy there are no lump sum transfer sow $=\frac{E}{T}$, and equilibrium life time endowments can be presented such as:

$\mathrm{w} *=\frac{1}{\mathrm{~T}} \int_{0}^{\mathrm{T}} \mathrm{W}(\mathrm{t}) \mathrm{e}^{-\mathrm{rt}} \mathrm{dt}(87)$

Aggregate money holdings between ages $j \tau$ and $(j+1) \tau$ are:

$m_{j}=\int_{j \tau}^{(j+1) \tau} W_{j} \frac{(j+1) \tau-t}{\tau} e^{-\pi(t-j \tau)} d t=$

$\mathrm{W}_{j} \frac{e^{-\pi \tau}+\pi \tau-1}{\pi^{2} \tau}$

In general Romer (1986) version, is general equilibrium model, where one can see and study money demand, the effect on inflation on consumption the optimum quantity of money.
7. Financial instability and Diamond-Dybvig model

In the Diamond-Dybvig model $(1983)^{18}$ banks as financial intermediaries promote risk sharing among individuals, but also they are subject of intermediary panics. Authors at first explain that bank runs are common feature of extreme crises in monetary history. In the model there are three periods, i.e. $\mathrm{T}=1,2,3$. Also there are two existing and possible technologies. Investment of one unit of output at $\mathrm{T}=0$, yields one unit of output in period 0 and one unit of output in period 2. This is when one uses short technology to produce, but when one uses long technology to produce at $\mathrm{T}=0$, this yields 0 units of output in period one and more than one $r>1$ units in period 2. Individuals need not to specify the technology that they are using or exante choosing. The idea is that more roundabout technologies are more productive. They opt for a short run or long run technology depending on the harvesting of yield in period 1 or period 2. There exist two types of utility functions:

$\mathrm{U}\left(\mathrm{c}_{1} ; \mathrm{c}_{2} ; 1\right)=\mathrm{U}\left(\mathrm{c}_{1}\right)(89)$

$\mathrm{U}\left(\mathrm{c}_{1} ; \mathrm{c}_{2} ; 2\right)=\mathrm{U}\left(\mathrm{c}_{1}+\mathrm{c}_{2}\right)(90)$

\footnotetext{
${ }^{18}$ Diamond DW, Dybvig PH (1983). "Bank runs, deposit
} insurance, and liquidity". Journal of Political Economy91 (3) 
In the previous expression

$\lim _{c \rightarrow \infty} u^{\prime}(c)=\infty$ and $\lim _{c \rightarrow \infty} u^{\prime}(c)=$

$0 ;-\frac{c u^{\prime \prime}(c)}{u^{\prime}(c)}>1$. The person will choose

$c_{1}=1$ if turns out to be impatient and

$c_{2}=r$ if patient. Expected or average

utility of that person is given by the

following expression:

$\mathrm{EU}=\mathrm{pu}(1)+(1-\mathrm{p}) \mathrm{u}(\mathrm{r})(91)$

So, agents (people) can do better than this if there are intermediaries. And, now some benevolent social planner would withdraw 1-x from the investment on $\mathrm{T}=1$, so as to maximize the expected utility of a representative individual.

$\mathrm{pu}\left(\mathrm{c}_{1}^{1}\right)+(1-\mathrm{p}) \mathrm{u}\left(\mathrm{c}_{1}^{2}+\mathrm{c}_{2}^{2}\right)(92)$

Previous expression is subject to resource constraint:

$p\left(c_{1}^{1}\right)+(1-p)\left(c_{1}^{2}\right)=1-x(93)$

$(1-\mathrm{p})\left(\mathrm{c}_{1}^{2}\right)=\mathrm{rx}$

In the previous expression in general $c_{i}^{j}$ are the resources that type $i$ consumes in period $j$. It is always optimal that $c_{1}^{2}=0$. Now the simpler problem to maximize is given by:

$\max _{c_{1}^{1}, c_{2}^{2}} p u\left(c_{1}^{1}\right)+(1-p) u\left(c_{2}^{2}\right)(94)$

The last expression is being maximized subject to:

$\mathrm{p}\left(\mathrm{c}_{1}^{1}\right)+(1-\mathrm{p}) \frac{\left(\mathrm{c}_{1}^{2}\right)}{r}=1(95)$ and if $\lambda$ is the Lagrangian,the first order conditions for maximization are given by the expression:

$u^{\prime}\left(c_{1}^{1}\right)=\lambda$

$u^{\prime}\left(c_{2}^{2}\right)=\lambda / r(96)$

$\frac{u^{\prime}\left(c_{1}^{1}\right)}{u^{\prime}\left(c_{2}^{2}\right)}=r$

The budget constraint of the social planner is given by the following expression:

$c_{2}^{2}=\frac{r}{1-p}-\frac{p r}{1-p} c_{1}^{1}(97)$

Now, there are banks in our economy as they exist in reality too. Let's consider that there exists bank contracts. Such a contract so that everyone deposits their resources in the bank at time $\mathrm{T}=0$.So, those that are patient people can withdraw money $r_{1}>1$ in period 1. Their withdrawals will be monitored by the bank. Patient depositors will get their pro rata of what is left after period one withdrawal. Banks will implement social optimum $r_{1}=c_{1}^{1 *}$, where in the previous expression asterisk denotes social optimum. But some fraction of the depositors, those impatient will withdraw money at period, then the patient consume balance $\frac{r\left(1-p c_{1}^{1 *}\right)}{1-p}=c_{2}^{2 *}$. Now, lets suppose that $V_{1}$ is the payoff one gets when one withdraws in period one, $V_{2}$ is the payoff that one gets in period two if one does not withdraw in period one. 
Because the payoff depends on the place one has in the line, if $f_{j}$ denotes the number of the depositors served before depositor $\mathrm{j}$ on date one, and if $f$ represents the total number of withdrawals on date one than one can have:

$V_{1}\left(f_{j}, r_{1}\right)=\left\{\begin{array}{l}r_{1} \text { if } f_{j} r_{1}<1 \\ 0 \text { if } f_{j} r_{1} \geq 1\end{array}\right.$

And if:

$\mathrm{V}_{2}\left(\mathrm{f}, \mathrm{r}_{1}\right)=\max \left\{\frac{\mathrm{r}\left(1-\mathrm{r}_{1} \mathrm{f}\right)}{1-\mathrm{f}}, 0\right\}(99)$

The first best equilibrium is such that $f=$ $p:$

$\mathrm{V}_{2}\left(\mathrm{f}, \mathrm{r}_{1}\right)=\mathrm{V}_{2}\left(\mathrm{f}, c_{1}^{1 *}\right)=\frac{\mathrm{r}\left(1-\mathrm{pc}_{1}^{1 *}\right)}{1-\mathrm{p}}=c_{2}^{2 *}$

So now if $r_{1}=1$ then we would have $\mathrm{V}_{2}(\mathrm{f}, 1)=\max \{\mathrm{r}, 0\}=$ rand the patient types of depositors would never have incentive to withdraw at period one. To do better we need $r>1$, either way banks would never be better than autarky. So when $r>1$ there would be a depositor panic and run on the bank. Now if $=\frac{1}{r_{1}}$, the depositors one can expect to withdraw all of their deposits at $\mathrm{T}=1$, thus making $V\left(\frac{1}{r_{1}}, r_{1}\right)=$ 0 ,so now every depositor has incentive to join the front of the queue of depositors in front of the bank, in hope one to get his money out. So in this equilibrium everyone will do the same and some depositors will be left empty handed. No depositor will get money at $\mathrm{T}=2$. The bank thus will have failed. Now, will get back shortly the notion that by assumption that relative risk aversion $r>1$, and since relative risk aversion always exceeds 1 , the optimal consumption levels will satisfy these conditions:

$c_{1}^{1 *}>1 \mathrm{and} c_{2}^{2 *}>r$

The proof for the last according to the Diamond and Dybvig (1983)

$$
\begin{aligned}
& \operatorname{pru}^{\prime}(r)<r u^{\prime}(r) \\
& =1 * u^{\prime}(1)+\int_{\varphi=1}^{r} \frac{\partial}{\partial \varphi}\left[\varphi u^{\prime}(\varphi)\right] d \varphi \\
& =u^{\prime}(1)+\int_{\varphi=1}^{r}\left[u^{\prime}(\varphi)+\right. \\
& \left.u^{\prime \prime}(\varphi)\right] d \varphi<u^{\prime}(1)(101)
\end{aligned}
$$

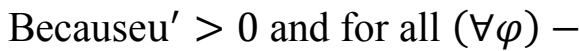
$\frac{u^{\prime \prime}(\varphi) \varphi}{u^{\prime}(\varphi)}>1$.

\section{Conclusion}

In the late 1970's most of the economist declared as new-classical. It seems that all of the best macroeconomics were at newclassical economics side, Gordon(1990) ${ }^{19}$. Yet, Keynesian macroeconomics reemerged again. Nowadays, it is proven in 1990's and 2000's also that the newclassical macroeconomics prove to be very

\footnotetext{
${ }^{19}$ Gordon,J.,R.,(1990), What is New-Keynesian Economics?, Journal of economics literature, Vol. XXVIII
} 
wrong. Nowadays good guys in economics are new-keynesians and not new-classical economists. It seems that just when the new Keynesian economics was been declared dead, the best papers in Keynesian economics and in economics in general had been written by Keynesian economists. Neo-classical synthesis long run, might just be too long so government and central bank policies are needed.

\section{References}

[1] Akerlof, George A \&Yellen, Janet L, (1987). "Rational Models of Irrational Behavior," American Economic Review, American Economic Association, vol. 77(2), pages 137-42, May

[2] Akerlof, George A, (1970). "The Market for 'Lemons': Quality Uncertainty and the Market Mechanism," The Quarterly Journal of Economics, MIT Press, vol. 84(3), pages 488-500, August.

[3] Akerlof, George A, (1979). Irving Fisher on His Head: The Consequences of Constant ThresholdTarget Monitoring of Money Holdings, The Quarterly Journal of Economics, MIT Press, vol. 93(2), pages 169-87, May.
[4] Baumol, William J. and Tobin, James (1989), "The Optimal Cash Balance Proposition: Maurice Allais' Priority", Journal of Economic Literature, September, Vol. 27, No. 3, pp. $1160-1162$

[5] Baumol, William J., (1952), "The Transactions Demand for Cash: An Inventory

Theoretic Approach", Quarterly Journal of Economics, November, vol. 66, pp. 545-556.

[6] Caballero, Ricardo J \& Engel, Eduardo M R A \&Haltiwanger, John, (1997). Aggregate Employment Dynamics: Building from Microeconomic Evidence, American Economic Review, American Economic Association, vol. 87(1), and pages 115-37, March.

[7] Diamond DW, Dybvig PH (1983). "Bank runs, deposit insurance, and liquidity". Journal of Political Economy91 (3): 401-419. doi:10.1086/261155. JSTOR 1837095. Reprinted (2000) Fed Res Bank Mn $Q$ Rev24 (1), 14-23.

[8] Gordon,J.,R.,(1990), What is NewKeynesian Economics?, Journal of economics literature, Vol. XXVIII

[9] Jovanovic, Boyan, (1982), "Inflation and Welfare in the Steady

State", Journal of Political Economy, vol. 90, no. 3, pp. 561-577.

[10] Miller, M. \& Orr, D. (1966). A model of the demand for money by firms. The 
Quarterly Journal of Economics, 81, 413-435

[11] Romer,D.(1986), A simple general equilibrium version of the baumoltobin model*, The quarterly journal of economics

[12] Romer,D.,(1987), The monetary transmission mechanism in a general equilibrium version of the TobinBaumol model, Journal of Monetary Economics, 20(1987

[13] Rothschild, M. , J. E. Stiglitz: (1976), "Equilibrium in Competitive Insurance Markets: An Essay on the Economics of Imperfect Information", Quarterly Journal of Economics, 90, 1976, 629-649.

[14] Sidrauski, Miguel (1967). "Rational Choice and Patterns of Growth in a Monetary Economy". American Economic Review 57 (2): 534-544.

[15] Taylor,B.,J.,(1980),Aggregate dynamics and staggered contracts, The journal of political economy, Vol.88
[16] Thomas J. Sargent \& Neil Wallace, (1981). "Some unpleasant monetarist arithmetic," Quarterly Review, Federal Reserve Bank of Minneapolis, issue Fall

[17] Tobin, James, (1956), "The Interest Elasticity of the Transactions Demand for Cash", Review of Economics and Statistics, August, vol. 38, no. 3, pp. 241-247. 